\author{
답리작 사료작물의 랩사일리지 생산비 분석 \\ 하유신 · 박경규
}

\title{
Cost Analysis of Wrap Silage Production in the Paddy Field for Forage Crop Cropping System
}

\author{
Yu Shin Ha and Kyung Kyoo Park
}

\begin{abstract}
Mechanized operation model and mechanical cultivation technology for winter barley, rye, Italian ryegrass and sudan grass wrap silage production system at the paddy field for cropping system was developed. Also, a series of experiment were performed and lots of data were collected and analyzed to develope mechanical technology, coverage area, and optimum size of the farm (break-even point) for wrap silage production system. The coverage area for winter barley or rye wrap-silage production system is determined around $61.9,73.4,77.5,88.2$ ha in the case of drill seeding and different ripening species by tractor power $50,75,100,130 \mathrm{ps}$, respectably. The break-even point of the farming size is analyzed as 20 ha and its production cost is estimated around 367, 383, 430, 443 won/TDN-kg in the case of winter barley wrap-silage by tractor power $50,75,100,130 \mathrm{ps,} \mathrm{respectably.} \mathrm{The} \mathrm{break-even} \mathrm{point} \mathrm{of} \mathrm{the} \mathrm{farming} \mathrm{size} \mathrm{is}$ analyzed as coverage area and its production cost is estimated around 237, 215 won/TDN-kg in the case of winter barley wrap silage and sudan grass by the tractor power $50,100 \mathrm{ps}$, respectably.
\end{abstract}

(Key words : Wrap silage, Mechanized production, Coverage area, Cost analysis, Cropping system)

\section{I. 서 론}

우리나라 사료작물 생산기반은 1990년 이후 계속 감소하는 추세를 보였으나 최근 청보리 사업을 중심으로 한 겨울철 사료작물, 즉 답리 작 조사료 재배 면적이 234천 ha이며, 여름철 사료작물도 40 천 ha로 계속 증가하고 있다(KREI, 2010). 이러한 증가 요인으로는 늘어나는 쌀 재 고량 조절을 위해 논에 벼 대체 사료작물 재배 를 유도하여 적정 벼 재배면적의 유지와 쌀 생 산량을 조절하는 동시에 조사료의 생산 및 이 용을 확대하고자 함이다.

겨울철 답리작으로 재배되는 벼 대체 사료작
물로는 보리, 호밀, 이탈리안라이그라스(IRG) 등이 대표적이고, 여름 사료 작물로는 수단그 라스, 수수류, 사료용 벼 등이 있다. 최근에는 사료작물의 재배도 겨울 조사료와 여름 조사료 의 작부체계로 재배되고 있다. 이러한 사료작 물의 작부체계에 대한 연구는 국내외에서 많은 연구자들에 의해 보고되어 왔다 (Hagino et al., 1999; Haizel, 1974; James and Obura, 1982; Kang et al., 2009; Kim et al., 2005; Lee and Lee, 1989). 이 연구는 대부분 논이나 밭에서 여 름철 및 겨울철 사료작물을 재배하여 최대 생산 을 높이기 위한 작부체계 설정에 관한 것이다.

조사료 생산의 경제적인 측면에서 조사료 재

경북대학교 (Kyungpook National University, Daegu, 702-701, Korea)

Corresponding author: Kyung Kyoo Park, Kyungpook National University, Daegu, 702-701, Korea,

Tel: +82-53-950-5792, Fax: +82-53-950-6780, E-mail: kkpark@knu.ac.kr 
배 품종이나 조사료 재배 방법을 달리하여 생 산성과 사료 가치를 높이면 자연적으로 생산비 용을 낮출 수 있다. 그렇지만 조사료 생산에 필요한 소요 작업기계의 가격, 종류, 크기, 작 업성능, 연료소모율, 기계화 작업방법 등에 따 라서도 생산비용은 달라질 수 있다. Kim 등 (2003)과 Park 등 (2003)은 겨울철 호맥 생산에 소요되는 작업공정과 소요 기계의 종류에 따른 기계 이용비용, 생산비용 등을 제시하였다. 이 는 규모화되지 않은 포장에서 단순히 겨울철에 재배되는 호밀 사일리지 생산에 대한 연구 결 과이다. 그러나 최근 우리나라 수도작 재배지 역에 겨울철과 여름철에 걸쳐 사료작물이 생산 되고 있기 때문에 수도작 대체용 조사료 생산 에 소요되는 작물별 부담면적, 기계 이용비용, 조사료 생산비용 등에 관한 연구가 필요하다.

본 연구는 겨울철과 여름철에 답리작 사료작 물의 랩사일리지 생산에서 연구보고된 조사료 재배품종과 재배방법을 기준으로 하였을 때, 소요 기계에 따른 기계화 생산 작업의 특성과 기계 이용비용을 분석하여 조사료 생산비용을 산출하였다.

\section{ㅍ. 재료 및 방법}

\section{1. 답리작 랩사일리지 생산작업}

랩사일리지의 생산작업은 경상북도 상주시 함창읍 오사리에서 2009년에서 2010년에 수행 되었으며, 포장의 전체 면적은 약 $100 \mathrm{ha}$ 인 대 규모 경지정리지구로서 길이가 $100 \mathrm{~m}$ 인 직사각 형 포장으로 이루어져 있다. 랩사일리지 생산 작업을 통하여 기계화 작업의 공정별 특성을 분석하고, 생산비 분석에 필요한 포장작업 관 련 계수 등의 실제적인 자료를 수집하였다.

하계작물은 5 6월, 동계작물은 9 10월에 파 종작업을 실시하였으며, 동계작물은 5 6월, 하 계작물은 8 9월에 수확작업을 실시하였다. 파 종작업은 2 명의 인원이 2 대의 트랙터를 이용하
여 경운 후 산파와 조파작업을 실시하였고, 소 요된 기계의 제원을 Table 1에 나타내었다. 소 요기계에서 직경 $1 \mathrm{~m}$ 인 원형베일을 생산하는 모델을 소규모 모델, 직경이 $1.2 \mathrm{~m}$ 인 것을 대규 모 모델로 분류하여 분석하였다.

동계작물은 호밀 (Maton), IRG (Primecut), 청 보리 (영양)를 이용하였고, 하계작물은 수단그 라스(Turbogold)를 이용하였다. 파종작업은 경 운 후 산파, 조파의 방법을 택하였고 산파는 파종전 로타리, 산파, 얕은 갈이 (로타리), 비료 살포의 순서로 작업이 진행되었고, 조파는 파 종전 로타리, 얕은 갈이, 조파, 비료살포, 복토, 추비의 순서로 진행되었다. 파종량과 시비량은 호밀의 경우 산파는 $145 \mathrm{~kg} / \mathrm{ha}$, 조파는 120 $\mathrm{kg} / \mathrm{ha}$, 기비는 복합비료 $180 \mathrm{~kg} / \mathrm{ha}$, 추비는 요소 $180 \mathrm{~kg} / \mathrm{ha}$ 을 적용하였고, 청보리의 경우 산파는 $170 \mathrm{~kg} / \mathrm{ha}$, 조파는 $105 \mathrm{~kg} / \mathrm{ha}$, 기비는 복합비료 $140 \mathrm{~kg} / \mathrm{ha}$, 추비는 요소 $120 \mathrm{~kg} / \mathrm{ha}, \mathrm{IRG}$ 의 경우 산파는 $45 \mathrm{~kg} / \mathrm{ha}$, 조파는 $35 \mathrm{~kg} / \mathrm{ha}$, 기비는 복합 비료 $350 \mathrm{~kg} / \mathrm{ha}$, 추비는 요소 $150 \mathrm{~kg} / \mathrm{ha}$, 수단그 라스의 경우 산파는 $50 \mathrm{~kg} / \mathrm{ha}$, 조파는 $35 \mathrm{~kg} / \mathrm{ha}$, 기비는 복합비료 $350 \mathrm{~kg} / \mathrm{ha}$, 추비는 요소 150 $\mathrm{kg} / \mathrm{ha}$ 을 적용하였다. 당시 일기불순에 의한 콤 바인 작업의 지연과 논이 마르지 않은 관계로 상당히 늦은 시기의 파종이 이루어질 수밖에 없었으며 파종 상태도 매우 불량하였다.

랩사일리지 수확작업은 제시된 기계화 일관 작업의 방법으로 시행하였다. 수확 작업의 절 차를 요약하면 예취(모어), 예건/집초/반전 (레 이크), 수집/압축/결속 (베일러), 피복/밀봉 (베일 랩퍼), 적재 (핸들러), 운반 (트레일러), 저장 (핸 들러)의 순서로 작업이 진행되었다.

\section{2. 랩사일리지 부담면적 산출}

랩사일리지 가공은 단일 작업공정이 아닌 여 러 작업의 복합공정으로 연속적으로 진행이 되 어진다. 따라서 기존의 수도작이나 전작에 비 해 그 작업 공정이 복잡하며 부담면적의 확대 
Table 1. Specifications of wrap silage production machine

\begin{tabular}{|c|c|c|}
\hline & Process & Machine \\
\hline \multirow{5}{*}{ Seeding } & Fertilization & Tractor $(57 \mathrm{ps})+$ Fertilizer broadcaster $(320 \mathrm{~kg})$ \\
\hline & \multirow{2}{*}{ Cultivation } & Tractor $(130 \mathrm{ps})+$ Rotavator $(258 \mathrm{~cm})$ \\
\hline & & Tractor $(82 \mathrm{ps})+$ Rotavator $(220 \mathrm{~cm})$ \\
\hline & \multirow{2}{*}{ Seeding } & Tractor $(57 \mathrm{ps})+$ Fertilizer broadcaster $(320 \mathrm{~kg})$ \\
\hline & & Power sprayer (knapsack type) \\
\hline \multirow{10}{*}{ Harvesting } & \multirow{2}{*}{ Mowing } & Tractor $(130 \mathrm{ps})+$ Mower $(240 \mathrm{~cm}$, conditioner $)$ \\
\hline & & Tractor $(82 \mathrm{ps})+\operatorname{Mower}(165 \mathrm{~cm})$ \\
\hline & \multirow{2}{*}{ Raking } & Tractor (70ps) + Raker (415 cm) \\
\hline & & Tractor $(45 \mathrm{ps})+$ Raker $(320 \mathrm{~cm})$ \\
\hline & \multirow{2}{*}{ Baling } & Tractor (130ps) + Baler (1.2 m, pickup $190 \mathrm{~cm})$ \\
\hline & & Tractor (45ps) + Baler (1.0 m, pickup $132 \mathrm{~cm})$ \\
\hline & \multirow{2}{*}{ Wrapping } & Tractor $(100 \mathrm{ps})+$ Wrapper $(165 \times 125 \mathrm{~cm})$ \\
\hline & & Tractor $(55 \mathrm{ps})+$ Wrapper $(100 \times 100 \mathrm{~cm})$ \\
\hline & \multirow{2}{*}{ Conveying } & Truck (2.5ton): 6 bales $/ 500 \mathrm{~kg}$ \\
\hline & & Truck (1ton): 4 bales $/ 500 \mathrm{~kg}, 6$ bales $/ 300 \mathrm{~kg}$ \\
\hline
\end{tabular}

에도 많은 제약이 따르게 된다. 랩-사일리지 생산의 부담면적의 계산은 작물의 예취, 건조, 수집, 가공의 작업이 일정기간 내에 연속적으 로 수행되어야 한다는 것을 전제로 하여 계산 되었다.

부담면적은 연간 작업가능 일수의 조사, 트 랙터 대수에 따른 작업 공정의 분석, 1 회 작업 시의 전체 작업일수의 결정, 1 회 작업일수 내 의 공정별 1 일당 작업가능 면적의 분석, 작업 가능 일수 내의 공정별 부담면적의 순서로 산 출하였다.

\section{1) 연중 작업가능 일수의 결정}

랩사일리지 조사료의 생산은 작업 시기의 특 성상 작업가능 기간이 제한되어 있다. 즉, 생산 작업은 파종작업과 수확작업으로 나누어 볼 수 있는데, 답리작 맥류의 파종은 벼 수확 직후에 서 파종 한계기 사이에서 파종이 가능하다. 그 러나 답리작 맥류 조사료의 가격유지를 위해서
는 충분한 수량의 확보가 가능해야 하며 이를 위해서는 적기에 파종이 이루어져야 한다. 대 체로 맥류 파종적기는 10 월 중-하순이며 9월 하순에서 시작되는 벼의 수확기를 고려한다면 파종 가능 기간은 약 20 일 정도일 것으로 판단 하였다. 또한 맥류 조사료 수확의 경우는 이앙 기 이전의 수확적기에 작업을 완료해야 하므로 작업기간은 약 30 일 정도가 될 것으로 판단된 다. 그런데, 이러한 20 일간의 작업 가능 기간 동안 모두 작업이 가능한 것은 아니며 지역별 기후 및 토질, 또는 기타 사정에 의해 작업 가 능 일수는 제한받는다. 이를 작업 가능 일수율 이라 하는데 보고된 자료 (Park, 2008) 중에서 $10 \sim 11$ 월 중의 경운 작업 가능 일수율의 평균치 $80 \%$ 를 파종작업 가능 일수율로 대체하고 사일 리지 수확작업은 조사된 자료 (Park et al., 2003) 와 우리나라 6월중의 맥류 알곡의 수확작업 가 능 일수율 $60 \%$ 를 맥류 조사료 수확작업 가능 일수율로 대체하였다. 
2) 1 회 작업시 작업일수의 결정

랩사일리지 조사료의 수확작업의 특징 중의 하나는 작업의 전 공정이 연속적으로 이루어지 며 또한 전체 작업의 완료시점이 제약을 받는 다는 점이다. 즉, 랩사일리지의 경우 예취된 작 물을 예건하고 이를 압축, 결속한 이후 최대한 24시간 이내에 랩핑 작업이 이루어져야 하며 양질의 사일리지 가공을 위해서는 당일 예취한 작물은 당일 랩핑 처리를 완료하는 것이 필수 적이다. 따라서 랩사일리지 생산의 1 회 작업시 의 작업일수는 1 일로 하였다.

\section{3) 작업 공정별 ha당 작업 소요일수의 산출}

농작업에서의 포장 작업 성능은 대체로 기계 적인 요인, 포장의 구조적 요인, 그리고 기타 요인에 영향 받는 것으로 분류할 수 있다 (Park, 2008). 기계적 요인으로는 동력원과 작업 특성 에 따른 기계의 작업폭, 작업 속도, 기계의 고 장율을 들 수 있고, 포장의 구조적 요인으로는 포장의 크기, 형상, 주행성 등을 들 수 있다. 또한 그 외의 기타 요인으로는 운전자의 기술, 기상조건 등을 들 수 있고 포장의 분산정도는 전체 작업 가능 일수에 매우 중요한 영향을 미 친다. 본 연구에서는 이들에 대한 기존의 데이 터와 상주 함창 지역에서 실제 작업을 수행하 여 이론 작업량, 실포장 작업량, 포장 작업 효 율, 실작업률 등을 조사한 데이터를 비교 분석 하여 최종적으로 작업 공정별 ha당 작업 소요 일수를 계산하였다 (Park et al., 2003; Park, 2008). 이 때, 포장 작업 성능에 영향을 미치는 요인 중에서 기계의 작업폭, 속도, 포장의 크기 등에 대해서는 어느 정도 그 영향을 반영할 수 있었지만 기계의 개별 고장율, 포장의 형상과 주행성, 운전자의 기술 및 포장의 분산정도 등 은 고려 대상에서 제외하였다.

\section{3. 랩사일리지 생산비 산출}

랩사일리지 생산비는 작물종류 (호밀, 청보리,
$\mathrm{IRG}$, 수단그라스), 파종방법 (산파, 조파)과 트 랙터 마력 $(50,75,100,130 \mathrm{ps})$ 에 따른 경작규 모별 (부담면적 ha별), 부담면적대비 경작지 비 율별 $(25,50,75,100 \%)$, 작부체계별 (품종 숙기 별, 동-하계 작물별)로 분류하여 산출하였다. 품종 숙기별 생산비 산출은 동일 경작규모에 동계작물인 호밀, 청보리, IRG를 단일 품종으 로 재배하였을 때와 동일 경작규모에 호밀, 청 보리, IRG를 동반 재배하였을 경우이다. 생산 비용 분석은 고정비, 변동비, 재료비, 토지용역 비, 작물별 생산량 등으로 분류하였고, $\mathrm{Kim}$ 등 (2003)과 Park 등 (2003)이 제시한 방법을 기준 으로 산출하였다.

고정비에서 내구연한은 여러 자료를 참조하 여 (Park et al., 2003; RDA, 2008) 파종 작업용 작업기는 8년, 조사료 수확용 작업기 및 트랙 터에 대하여는 10 년으로 하였고, 기계의 폐기 가격은 구입 가격의 $10 \%$ 로 하였으며, 감가상 각비는 직선법을 이용하여 산출하였다 (Park, 2008). 이자는 농림부의 농기계 구입 자금 지원 규정인 기계 구입가의 융자분에 대해서는 연리 $3 \%$ 정도의 조건이 적용 가능하고(MIFAFF. 2010), 나머지에 대해서는 일반 대출 금리를 적 용할 수 있으므로 이를 통합하여 일률적으로 기계 구입가의 $6 \%$ 를 적용하고, 차고비는 기계 구입가의 $1 \%$ 로 적용하였다. 답리작에서의 조사 료 경작을 위한 임차비용은 지역별로 큰 차이 를 가지므로, 본 연구에서는 조사된 전국 평균 치인 912,040천 원/ha를 적용하였다(KAPA, 2009). 작업에 이용된 기계의 구입가격은 조사된 가격 을 기준으로 하였으며 (KAMICO, 2009), 신규 구입기계를 제외한 나머지 기종 (트랙터, 로타 리, 트레일러, 비료살포기 등)은 기 구입분을 사용하는 것으로 간주하였다. 기계의 가격과 규격을 Table 2에 나타내었다.

변동비는 다음과 같이 산출하였다. 연료비는 작업별 트랙터의 부하를 추정하여 시간당 소요 연료량을 구한 다음 단위 연료비의 곱으로 나 타내었으며, 윤활유비는 작업별 시간당 연료비 
Table 2. Summary of purchasing price of wrap silage production machine

\begin{tabular}{|c|c|c|c|c|c|c|}
\hline \multirow{2}{*}{ Process } & \multirow{2}{*}{ Implements } & & \multicolumn{4}{|c|}{ Tractor power (ps) } \\
\hline & & & 50 & 75 & 100 & 130 \\
\hline- & Tractor & Price (1000 won) & 24,800 & 39,400 & 62,000 & 82,570 \\
\hline \multirow{4}{*}{$\begin{array}{l}\text { Broadcast } \\
\text { seeding }\end{array}$} & \multirow{2}{*}{ Rotavator } & Specification (m) & 1.8 & 2.2 & 2.3 & 2.8 \\
\hline & & Price (1000 won) & 3,360 & 5,450 & 7,200 & 8,100 \\
\hline & \multirow{2}{*}{$\begin{array}{l}\text { Fertilizer } \\
\text { broadcaster }\end{array}$} & Specification (kg) & 300 & 400 & 500 & 600 \\
\hline & & Price (1000 won) & 750 & 920 & 1,200 & 1,400 \\
\hline \multirow{6}{*}{$\begin{array}{l}\text { Drill } \\
\text { Seeding }\end{array}$} & \multirow{2}{*}{ Rotavator } & Specification (m) & 1.8 & 2.2 & 2.3 & 2.8 \\
\hline & & Price (1000 won) & 3,360 & 5,450 & 7,200 & 8,100 \\
\hline & \multirow{2}{*}{ Direct seeder } & Specification (row) & 8 & 9 & 10 & 11 \\
\hline & & Price (1000 won) & 8,800 & 9,500 & 9,500 & 10,300 \\
\hline & \multirow{2}{*}{$\begin{array}{l}\text { Fertilizer } \\
\text { broadcaster }\end{array}$} & Specification (kg) & 300 & 400 & 500 & 600 \\
\hline & & Price (1000 won) & 750 & 920 & 1,200 & 1,400 \\
\hline \multirow{12}{*}{ Harvesting } & \multirow{2}{*}{ Mower } & Specification (m) & 1.65 & 2.15 & 2.40 & 2.40 \\
\hline & & Price (1000 won) & 6,200 & 7,600 & 19,000 & 19,000 \\
\hline & \multirow{2}{*}{ Raker } & Specification (m) & 3.2 & 4.2 & 4.2 & 4.2 \\
\hline & & Price (1000 won) & 3,800 & 4,600 & 4,600 & 4,600 \\
\hline & \multirow{2}{*}{ Baler } & Specification (m) & 1.3 & 1.3 & 1.9 & 1.9 \\
\hline & & Price (1000 won) & 25,700 & 25,700 & 42,500 & 42,500 \\
\hline & \multirow{2}{*}{ Wrapper } & Specification (m) & $1.0 \times 1.0$ & $1.2 \times 1.2$ & $1.2 \times 1.3$ & $1.2 \times 1.3$ \\
\hline & & Price (1000 won) & 13,200 & 14,000 & 22,000 & 22,000 \\
\hline & \multirow{2}{*}{ Handler } & Specification (ton) & 1.3 & 1.7 & 1.7 & 1.7 \\
\hline & & Price (1000 won) & 2,000 & 2,400 & 2,400 & 2,400 \\
\hline & \multirow{2}{*}{ Trailer } & Specification (ton) & 4.3 & 4.3 & 4.3 & 4.3 \\
\hline & & Price (1000 won) & 2,930 & 2,930 & 2,930 & 2,930 \\
\hline
\end{tabular}

의 $10 \%$ 를 적용하였다 (Park, 2008; RDA, 2008). 시간당 수리비 계수는 문헌 (Park, 2008)을 참조 하여 결정하였다. 트랙터의 이용비용은 고정비 에서 언급된 것을 기준으로 하여 감가상각비 계수 0.09 , 이자 계수 0.033 , 차고비 계수 0.01 및 수리비 계수 0.07 의 합을 트랙터 고정비 계 수로 결정하였으며, 트랙터 총 사용시간은 수 도작 평균 사용시간 $500 \mathrm{hr}$ 과 공정별 작업시간 의 합으로 나타내었다 (Park et al., 2003; Park,
2008).

작물별 조사료의 생산에는 여러 가지의 재료 가 소요되는데, 이들의 상세 내용과 비용을 조 사하여 Table 3에 나타내었다. 비료는 파종시의 기비 및 이듬해 봄의 추비를 모두 고려하였고, 종자비는 $40 \%$ 를 정부보조로 받는 것으로 하였 다. 작물별 생산량은 $\mathrm{TDN}$ 기준으로 호밀은 $4.79 \mathrm{ton} / \mathrm{ha}$, 청보리는 $6.99 \mathrm{ton} / \mathrm{ha}$, IRG는 6.13 ton/ha, 수단은 8.92 ton/ha으로 나타났다. 
Table 3. Material cost

\begin{tabular}{|c|c|c|c|c|c|}
\hline $\begin{array}{l}\text { Forage } \\
\text { species }\end{array}$ & Material & Specification & Unit & $\begin{array}{l}\text { Cost } \\
\text { (won) }\end{array}$ & Usage per ha \\
\hline \multirow{5}{*}{ Rye } & Additives & Fermented liquor & $\mathrm{g}$ & 730 & 33 \\
\hline & \multirow{2}{*}{ Wrap vinyl } & $50 \mathrm{~cm} \times 1500 \mathrm{~m}$ & roll & 70,000 & 3.3 \\
\hline & & $75 \mathrm{~cm} \times 1500 \mathrm{~m}$ & roll & 95,000 & 1.8 \\
\hline & \multirow{2}{*}{ Bale net } & $1.02 \times 3000 \mathrm{~m}$ & roll & 200,000 & 0.26 \\
\hline & & $1.25 \times 3000 \mathrm{~m}$ & roll & 240,000 & 0.17 \\
\hline \multirow{5}{*}{ Barley } & Additives & Fermented liquor & g & 730 & 49 \\
\hline & \multirow{2}{*}{ Wrap vinyl } & $50 \mathrm{~cm} \times 1500 \mathrm{~m}$ & roll & 70,000 & 4.8 \\
\hline & & $75 \mathrm{~cm} \times 1500 \mathrm{~m}$ & roll & 95,000 & 2.7 \\
\hline & \multirow{2}{*}{ Bale net } & $1.02 \times 3000 \mathrm{~m}$ & roll & 200,000 & 0.38 \\
\hline & & $1.25 \times 3000 \mathrm{~m}$ & roll & 240,000 & 0.24 \\
\hline \multirow{5}{*}{ IRG } & Additives & Fermented liquor & $\mathrm{g}$ & 730 & 43 \\
\hline & \multirow{2}{*}{ Wrap vinyl } & $50 \mathrm{~cm} \times 1500 \mathrm{~m}$ & roll & 70,000 & 4.2 \\
\hline & & $75 \mathrm{~cm} \times 1500 \mathrm{~m}$ & roll & 95,000 & 2.3 \\
\hline & \multirow{2}{*}{ Bale net } & $1.02 \times 3000 \mathrm{~m}$ & roll & 200,000 & 0.21 \\
\hline & & $1.25 \times 3000 \mathrm{~m}$ & roll & 240,000 & 0.34 \\
\hline \multirow{5}{*}{$\begin{array}{l}\text { Sudan } \\
\text { grass }\end{array}$} & Additives & Fermented liquor & g & 730 & 62 \\
\hline & \multirow{2}{*}{ Wrap vinyl } & $50 \mathrm{~cm} \times 1500 \mathrm{~m}$ & roll & 70,000 & 6.2 \\
\hline & & $75 \mathrm{~cm} \times 1500 \mathrm{~m}$ & roll & 95,000 & 3.4 \\
\hline & \multirow{2}{*}{ Bale net } & $1.02 \times 3000 \mathrm{~m}$ & roll & 200,000 & 0.5 \\
\hline & & $1.25 \times 3000 \mathrm{~m}$ & roll & 240,000 & 0.31 \\
\hline
\end{tabular}

III. 결과 및 고찰

\section{1. 부담면적}

이론 작업량, 포장 작업 효율, 실작업률 등을 조사한 결과를 Table 4에 나타내었다. 공정별 소요 작업 일수는 파종 전·후 로터리 작업이 소규모 모델에서는 0.283 일/ha, 대규모 모델에 서는 0.189 일/ha로 가장 높게 나타났다. 이와 같은 수치들은 여러 상황에 따라 차이를 나타 낼 수 있으며 알려진 계수들도 일치하지 않고 있다(Hunt, 2001; Okamura, 1991; Park et al., 2003). 특히 포장의 규모와 형태를 반영하는 포 장작업효율은 작업의 특성상 상황에 따라 많은 편차를 가질 수밖에 없으며, 실제로 대규모의
초지작업을 고려한 기존의 계수들과 본 연구에 서 조사한 우리나라의 소규모 논을 이용한 작 업에서의 계수들은 큰 차이가 있었다.

조사된 Table 4의 계수값을 이용하여 모델별 부담면적을 구하여 Table 5에 나타내었다. 부담 면적은 트랙터 $100 \mathrm{ps}$ 일 경우 품종 숙기별 재 배에서 조파는 $77.5 \mathrm{ha}$ 로 나타났다.

단일작물 재배시나 품종 숙기별 재배 시에 트랙터 마력별로 부담면적은 산파의 경우보다 조파의 경우에 크게 나타났다. 조파는 얕은 갈 이, 파종, 복토를 동시에 작업할 수 있기 때문 에 산파보다 부담면적이 높게 나타났으며, 트 랙터 작업기의 규격과 추천 작업 속도 등이 한 정되어 있기 때문에 부담면적은 트랙터 마력에 비례하지 않는 것으로 나타났다. 또한 품종 숙 
Table 4. Coefficient values of working day per ha

\begin{tabular}{|c|c|c|c|c|c|c|c|}
\hline \multicolumn{3}{|c|}{ Item } & $\begin{array}{c}\text { Theoretical } \\
\text { working area } \\
(\mathrm{ha} / \mathrm{h})\end{array}$ & $\begin{array}{c}\text { Field } \\
\text { efficiency } \\
(\%) \\
\end{array}$ & $\begin{array}{c}\text { Net working } \\
\text { in a day } \\
\text { (h/day) }\end{array}$ & $\begin{array}{c}\text { Working area } \\
\text { in a day } \\
\text { (ha/day) }\end{array}$ & $\begin{array}{c}\text { Working day } \\
\text { per ha } \\
\text { (day/ha) } \\
\end{array}$ \\
\hline \multirow{9}{*}{$\begin{array}{l}\text { Small } \\
\text { scale }\end{array}$} & \multirow{4}{*}{ Seeding } & Fertilization & 2.75 & 54 & 9.60 & 14.30 & 0.070 \\
\hline & & Cultivation & 0.79 & 78 & 9.12 & 5.65 & 0.177 \\
\hline & & Seeding & 2.75 & 54 & 9.60 & 14.30 & 0.070 \\
\hline & & Cultivation & 1.32 & 78 & 9.12 & 9.39 & 0.106 \\
\hline & \multirow{5}{*}{ Harvesting } & Mowing & 1.07 & 70 & 10.20 & 7.65 & 0.131 \\
\hline & & Raking & 2.40 & 80 & 10.20 & 19.58 & 0.051 \\
\hline & & Baling & 0.79 & 60 & 9.60 & 4.61 & 0.217 \\
\hline & & Wrapping & 1.3 & 85 & 10.20 & 11.32 & 0.088 \\
\hline & & Conveying & 5.0 & 90 & 10.80 & 48.60 & 0.021 \\
\hline \multirow{9}{*}{$\begin{array}{l}\text { Large } \\
\text { scale }\end{array}$} & \multirow{4}{*}{ Seeding } & Fertilization & 3.25 & 54 & 9.60 & 31.20 & 0.032 \\
\hline & & Cultivation & 0.93 & 78 & 9.12 & 8.48 & 0.118 \\
\hline & & Seeding & 3.25 & 54 & 9.60 & 31.20 & 0.032 \\
\hline & & Cultivation & 1.55 & 78 & 9.12 & 14.14 & 0.071 \\
\hline & \multirow{5}{*}{ Harvesting } & Mowing & 1.80 & 70 & 10.20 & 18.36 & 0.054 \\
\hline & & Raking & 3.11 & 80 & 10.20 & 31.72 & 0.032 \\
\hline & & Baling & 1.14 & 60 & 9.60 & 10.94 & 0.091 \\
\hline & & Wrapping & 3.7 & 85 & 10.20 & 32.13 & 0.031 \\
\hline & & Conveying & 6.0 & 90 & 10.80 & 58.32 & 0.017 \\
\hline
\end{tabular}

Table 5. Coverage area by working process and tractor power

\begin{tabular}{cccccc}
\hline \multirow{2}{*}{ Item } & & \multicolumn{4}{c}{ Coverage area (ha) } \\
\cline { 2 - 5 } & & $\begin{array}{c}\text { Tractor } \\
(50 \mathrm{ps})\end{array}$ & $\begin{array}{c}\text { Tractor } \\
(75 \mathrm{ps})\end{array}$ & $\begin{array}{c}\text { Tractor } \\
(100 \mathrm{ps})\end{array}$ & $\begin{array}{c}\text { Tractor } \\
(130 \mathrm{ps})\end{array}$ \\
\hline \hline \multirow{2}{*}{$\begin{array}{c}\text { Single species } \\
\text { (Rye, Barley, IRG) }\end{array}$} & Broadcast seeding & 31.0 & 37.5 & 38.9 & 44.9 \\
\cline { 2 - 6 } $\begin{array}{c}\text { Different Ripening species } \\
\text { (Rye+Barley+IRG) }\end{array}$ & Drill Seeding & 41.3 & 49.0 & 57.1 & 58.8 \\
\cline { 2 - 6 } & Broadcast seeding & 46.5 & 56.2 & 58.3 & 67.3 \\
\hline
\end{tabular}

기별 재배는 호밀, 청보리, IRG를 같은 면적 비율로 파종 및 수확을 하기 때문에, 파종은 20 일에서 30 일로, 수확은 약 30 일에서 40 일로 시기가 늘어나기 때문에 부담면적이 늘어나는 것을 알 수 있다. 이는 호밀, IRG 및 청보리 등의 품종 숙기별 재배로 노동피크와 수확시기 의 분산, 품질향상 및 기계장비의 활용일수를
증대시킬 수 있을 것으로 판단되었다.

\section{2. 생산비용}

생산비용은 기계 이용 비용을 산출한 후 재료 비, 토지 임차비 등을 합한 비용을 구하였다. Fig. 1 에서는 부담면적별 생산 비용을 나타내었다. 


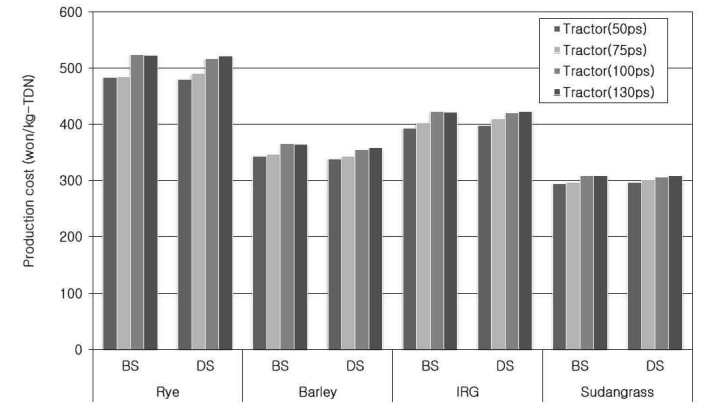

Fig. 1. Production costs by a coverage area (BS: Broadcast seeding, DS: Drill seeding).

작물별로 생산비용은 호밀이 가장 높으며 수 단이 가장 낮게 나타났는데 이는 단위면적당 생산량의 영향이 매우 크기 때문에 적기 파종 과 수확이 반드시 필요할 것으로 판단되었다. 파종방법별 생산비용은 산파(BS)가 조파(DS) 보다 약간 높게 나타났는데 이는 조파 작업기 의 높은 구입가격에도 불구하고 산파시 파종량 과 작업공정의 증가에 기인한 것으로 판단되었 다. 트랙터 마력별 생산비용은 마력수가 높을 수록 기계가격의 구입부담이 증가하여 높게 나 타났다. 또한 $50 \mathrm{ps}$ 와 $75 \mathrm{ps}, 100 \mathrm{ps}$ 와 $130 \mathrm{ps}$ 가 비슷한 수준으로 나타났는데, 이는 트랙터 마 력별로 작업기 기종의 차이가 거의 없고 추천 작업 속도 등이 비슷하기 때문인 것으로 판단 되었다.

부담면적 대비 경작지 비율별 생산비용은 Fig. 2와 같이 경작지 비율이 $50 \%, 50 \mathrm{ps}$ 트랙 터로 산파 작업시 $\mathrm{kg}$-TDN 기준으로 호밀은 540 원, 청보리는 387 원, IRG는 443원, 수단은 329원으로 나타났으며, $100 \mathrm{ps}$ 트랙터로 조파 작업시는 $\mathrm{kg}-\mathrm{TDN}$ 기준으로 호밀은 600 원, 청 보리는 412원, IRG는 485원, 수단은 350원으로 나타났다. 또한 경작지 비율이 부담면적에 접 근할수록 생산비용은 낮게 나타나고 있으며, 생산비용을 절감하기 위해서는 작업기를 효율 적으로 사용하는 것이 바람직한 것으로 판단되 었다. 경작규모별 생산비용은 $20 \mathrm{ha}$ (청보리 - 산

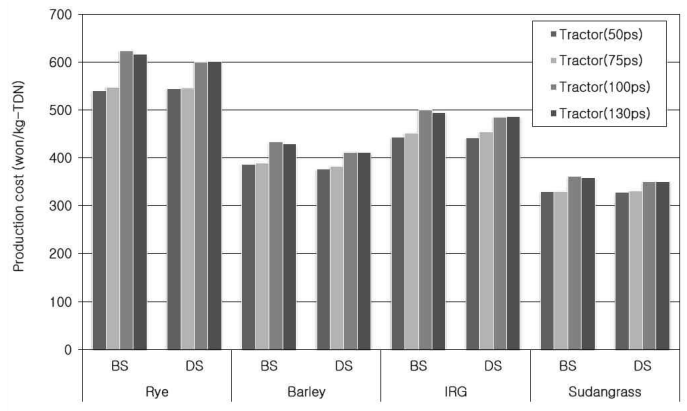

Fig. 2. Production costs by a cultivated land rate (BS: Broadcast seeding, DS: Drill seeding).

파-TDN 기준)일 경우 트랙터 마력별로 $50 \mathrm{ps}$ 는 367 원, $75 \mathrm{ps}$ 는 383 원, $100 \mathrm{ps}$ 는 430원, 130 $\mathrm{ps}$ 는 443원으로 나타났으며, $30 \mathrm{ha}$ 일 경우 트랙 터 마력별로 $50 \mathrm{ps}$ 는 344원, $75 \mathrm{ps}$ 는 357원, 100 $\mathrm{ps}$ 는 387 원, $130 \mathrm{ps}$ 는 398 원으로 나타났다. 경 작규모가 증가함에 따라 생산비용은 급격히 감 소를 하고 있으며, 약 $20 \mathrm{ha}$ 경작규모에 이르면 감소세가 완만한 것으로 나타났다.

품종 숙기별 생산비용은 동계작물인 호밀, 청보리, IRG를 단일 품종으로 재배하였을 경우 와 품종 숙기별로 호밀, 청보리, IRG를 동반 재배하였을 경우로 산출하였다. Fig. 3과 같이 $50 \mathrm{ps}$ 트랙터로 산파 작업시 $\mathrm{kg}-\mathrm{TDN}$ 기준으로 호밀, 청보리, IRG 동반 재배는 380 원, 호밀은 483원, 청보리는 343원, IRG는 393원으로 나타

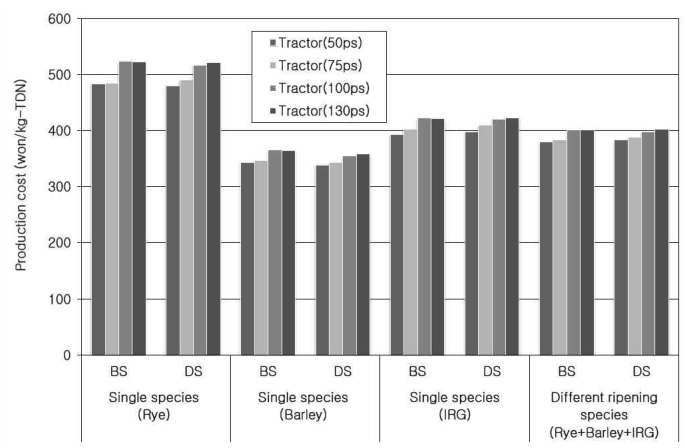

Fig. 3. Production costs by a single species and different ripening species (BS: Broadcast seeding, DS: Drill seeding). 


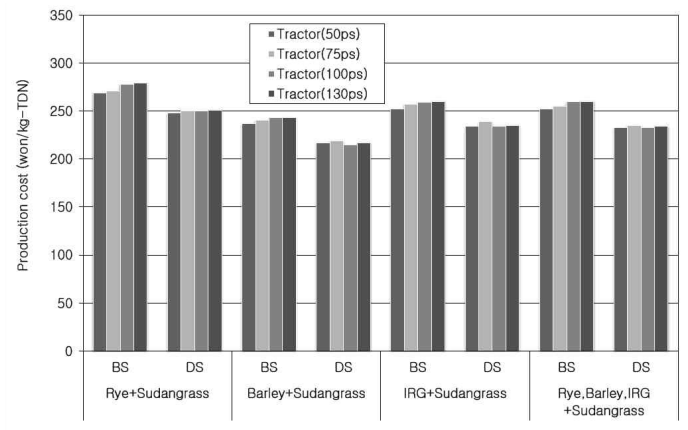

Fig. 4. Production costs by a cropping system (BS: Broadcast seeding, DS: Drill seeding).

났으며, $100 \mathrm{ps}$ 트랙터로 조파 작업시는 $\mathrm{kg}$ $\mathrm{TDN}$ 기준으로 호밀, 청보리, IRG 동반 재배는 398원, 호밀은 517원, 청보리는 355원, IRG는 420 원으로 나타났다. 품종 숙기별로 호밀, 청보 리, IRG의 동반 재배의 생산비용은 단일 품종 재배인 청보리보다 높고 호밀과 IRG 보다는 낮게 나타났는데, 이는 단위면적당 생산량의 영향 때문인 것으로 판단되었다.

동 - 하계작물 연중재배 시 생산비용은 Fig. 4 와 같이 $50 \mathrm{ps}$ 트랙터로 산파 작업시 $\mathrm{kg}$-TDN 기준으로 호밀 + 수단은 269원, 청보리 + 수단은 237원, IRG + 수단은 252원, 호밀 + 청보리 + $\mathrm{IRG}+$ 수단은 252 원으로 나타났으며, $100 \mathrm{ps}$ 트 랙터로 조파 작업시는 $\mathrm{kg}-\mathrm{TDN}$ 기준으로 작부 체계별 생산비용은 호밀 + 수단은 250원, 청보 리 + 수단은 215원, IRG + 수단은 234원, 호밀 + 청보리 $+\mathrm{IRG}+$ 수단은 233 원으로 나타났다. 이 는 연중 재배하지 않는 경우에 비해 고정비가 줄어들기 때문에 생산비용은 약 $30 ~ 50 \%$ 절감 되었으며, 기계-장비의 효율성을 제고할 수 있기 때문에 매우 유리할 것으로 판단되었다.

\section{IV. 요 약}

본 연구는 겨울철과 여름철에 답리작 사료작 물의 랩사일리지 생산에서 연구보고된 조사료 재배품종과 재배방법을 기준으로 하였을 때,
소요 기계에 따른 기계화 생산 작업의 특성과 부담면적, 기계 이용비용을 분석하여 조사료 생산비용을 산출하였다. 생산비용은 작물종류 (호밀, 청보리, IRG, 수단그라스), 파종방법 (산 파, 조파)과 트랙터 마력 $(50,75,100,130 \mathrm{ps})$ 에 따른 경작규모별 (부담면적 ha별), 부담면적대비 경작지비율별 $(25,50,75,100 \%)$, 작부체계별 (품종 숙기별, 동 - 하계 작물별)로 분류하여 산 출하였다. 트랙터 $100 \mathrm{ps,} \mathrm{조파를} \mathrm{기준으로} \mathrm{단}$ 일 품종 재배보다 호밀, $\mathrm{IRG}$ 와 청보리 등을 품 종 숙기별로 재배할 때 파종은 20 일에서 30 일 로, 수확은 약 30 일에서 40 일로 시기가 늘어나 기 때문에 부담면적이 $57.1 \mathrm{ha}$ 에서 $77.5 \mathrm{ha}$ 로 증 가하였다. 동 - 하계 작물 연중 재배시 생산비 용은 $100 \mathrm{ps}$ 트랙터, 조파, $\mathrm{kg}$-TDN 기준으로 호밀 + 수단은 250원, 청보리+수단은 215원, $\mathrm{IRG}+$ 수단은 234원, 호밀 + 청보리 + IRG + 수 단은 233 원으로 나타났다. 이는 연중 재배하지 않는 경우에 비해 고정비가 줄어들기 때문에 생산비용은 약 30 50\% 절감되었다. 따라서 답 리작 사료작물의 랩사일리지 생산시 노동피크 와 수확시기의 분산, 기계장비의 효율성을 제 고할 수 있도록 품종 숙기별 연중 재배 작부체 계의 이용이 바람직한 것으로 판단되었다.

$$
\text { V. 사 사 }
$$

본 연구는 경상북도 농수산기술개발사업의 지원에 의해 이루어진 것임

\section{VI. 인 용 문 헌}

1. Hagino, K., S. Sekimura, I. Katsura, K. OTA, T. Nakui and K. Takahashi. 1999. High yielding year-round cultivation of forage crops-corn (Zea mays L.)-rye (Secale cereale L.), barley (Hordeum vulgare L.) on rotational paddy fields in the Northern Tohoku District. Bul. of the Tohoku Natl. Agri. Expt. Station 95:27-36.

2. Haizel, K. A. 1974. The agronomic significance 
of mixed cropping: I. Maize interplanted with cowpea. Gha. J. of Agri. Sci. 7:169-178.

3. Hunt, D. 2001. Farm Power and Machinery Management (10th edition). A Blackwell Publishing Company. Ames. pp. 3-6.

4. James, R.A. and R.K. Obura. 1982. Yield of corn, cowpea, and soybean under different intercropping systems 1. Agron. J. 75(6):1005-1009.

5. KAMICO. 2009. Agricultural Machinery in Korea. Korea Agricultural Machinery Industry Cooperative, Seoul, Republic of Korea. pp 9-214.

6. Kang, D.S., D.H. Kim, H.Y. Shin, G.M. Son, C. W. Rho and J.G. Kim. 2009. Studies on cropping system for year-round cultivation of forage crops in Gyeongnam province. Journal of the Korean Society of Grassland and Forage Science 29(2): 137-152.

7. KAPA. 2009. The Official Land Value. Korea Association of Property Appraisers, Seoul, Republic of Korea.

8. Kim, H.J., K.K. Park, J.H. Seo and S.Y. Shin. 2003. Development of mechanized system model for the production of winter cereal wrap silage in the fallow paddy field(1) -Modelling mechanized roughage production system and previewing its profit-. Journal of Biosystems Engineering 28(2): 107-116.

9. Kim, W.H., J.S. Shin, Y.C. Lim, S. Seo, K.Y. Kim and J.K. Lee. 2005. Study on the promising double cropping system of summer and winter forage crop in paddy field. Journal of the Korean Society of Grassland Science 25(4):233-238.

10. KREI. 2010. Agricultural Outlook 2010(II). Korea Rural Economic Institute, Seoul, Republic of Korea. pp. 695-722.

11. Lee, S.S. and J.M. Lee. 1989. Corn-Based Forage Cropping Systems in Rice Black-Streaked Dwarf Virus Prevalent Area. Korean Journal of Crop Science 34(1):30-39.

12. MIFAFF. 2010. A Guide Book for Agriculture and Forestry-Vol.4:Livestock. Ministry for Food, Agriculture, Forestry and Fisheries, Gwacheon, Republic of Korea. pp. 617-632.

13. Okamura, T. 1991. Agricultural Mechanization Sciences. Hokkaido University, Sapporo, Japan. pp. 183-187.

14. Park, J.G. 2008. Bio-production Machinery Engineering. CIR, Seoul, Republic of Korea. pp. 16-32.

15. Park, K.K., H.J. Kim, T.H. Kim and Y.M. Koo. 2003. Development of mechanized system model for the production of winter cereal wrap silage in the fallow paddy field(2)-Cost analysis of mechanized wrap silge production-Journal of Biosystems Engineering 28(3):199-208.

16. RDA. 2008. Information Resources for Economic Analysis on Research. Rural Development Administration, Suwon, Republic of Korea. pp. 21-230.

(Received November 28, 2011/Accepted February 16, 2012) 